\title{
CORRIGENDUM
}

Genes \& Development 34: 118-131 (2020)

\section{Corrigendum: Control of noncoding RNA production and histone levels by a $5^{\prime}$ tRNA fragment}

Ana Boskovic, Xin Yang Bing, Ebru Kaymak, and Oliver J. Rando

In the above-mentioned article, a statement regarding the availability of the raw sequencing data sets (GEO accession GSE127247) was inadvertently omitted. This information has now been added to the article online under the additional heading "Data Availability."

doi: $10.1101 / \operatorname{gad} .336958 .120$ 


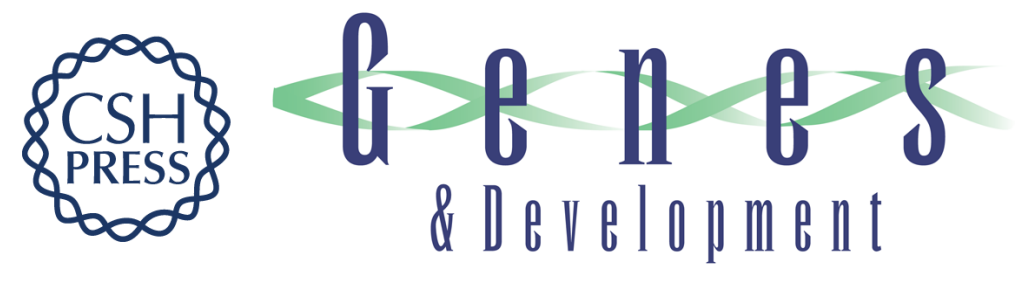

\section{Corrigendum: Control of noncoding RNA production and histone levels by a 5 ' tRNA fragment}

Ana Boskovic, Xin Yang Bing, Ebru Kaymak, et al.

Genes Dev. 2020, 34:

Access the most recent version at doi:10.1101/gad.336958.120
Related Content Control of noncoding RNA production and histone levels by a 52 tRNA fragment Ana Boskovic, Xin Yang Bing, Ebru Kaymak, et al.
Genes Dev. January, 2020 34: 118-131

\section{License}

Email Alerting

Receive free email alerts when new articles cite this article - sign up in the box at the top Service right corner of the article or click here.

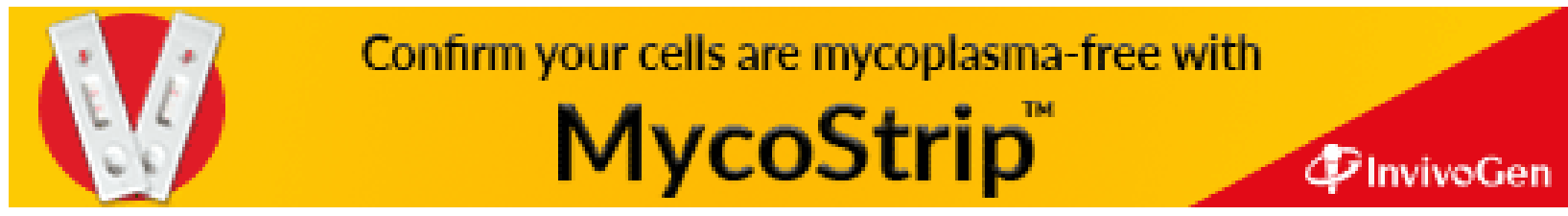

